\title{
Effects of Harvest Time on the Yield, Quality and Active Substance of Torreya grandis Nut and Its Oil
}

\author{
Yaping Wang ${ }^{1}$, Xiaohua Yao ${ }^{1 *}$, Liu Yang ${ }^{2}$, Xueqian Fei ${ }^{1}$, Yongqing Cao ${ }^{1}$, Kailiang Wang ${ }^{1}$, \\ and Shaohai Guo'
}

\author{
${ }^{1}$ Research Institute of Subtropical Forestry, Chinese Academy of Forestry (CAF), Hangzhou, ZJ 311400, CHINA \\ ${ }^{2}$ Zhejiang Academy of Forestry, Hangzhou, ZJ 310023, CHINA
}

\begin{abstract}
Torreya grandis is an important economic tree species in China. It provides nutritional value and is important to the health care industry. There are ongoing issues with product quality which are primarily related to improper management and early harvest. This study was carried out during the fruit ripening processes to evaluate the influence of harvesting date on $T$. grandis quality, and to determine the optimal harvest period. The effects of harvest time on the variation of quality and nutritional parameters of $T$. grandis nuts and its oil were evaluated, and the optimal harvest period was determined. The results showed that harvest timing had a strong effect on both oil yield and quality. Prolonged ripening could induce higher levels of kernel rate, fruit inclusions, oil and nutritional quality. When the sample harvested in the midSeptember, the kernel rate and oil content were increased by $1.88 \pm 0.31 \%$ and $6.65 \pm 0.47 \%$, respectively, compared to samples harvested in the beginning of late-August. Similarly, the mid-September harvest resulted in total unsaturated fatty acids content of the oil being increased by $5.3 \pm 0.34 \%$, the FFA and peroxide value being decreased by $40.7 \pm 0.15 \%$ and $76 \pm 0.08 \%$, respectively, and total tocopherols and free amino acids were increased $7.5 \pm 0.24 \%$ and $47.3 \pm 0.15 \%$, respectively, compared to the samples harvested on Aug. 25. The results indicated that the optimal harvest time of $T$. grandis fruits was mid-September as it was beneficial for improving the quality of $\boldsymbol{T}$. grandis nut and its oil. It was suggested that $\boldsymbol{T}$. grandis fruit should be harvested later.
\end{abstract}

Key words: Torreya grandis, harvest time, yield, quality, active substance

\section{Introduction}

Torreya grandis (T. grandis), also called Chinese torreya, is an evergreen tree of $T$. grandis genus Taxus. It is an important economic tree species in China and has been cultivated for more than 1300 years ${ }^{1)}$. T. grandis nuts are crispy and nutritious, and the oil content of the kernel is about $65 \%$. The primary fatty acids in the oil are linoleic acid and oleic acid, which include $79.41 \%$ unsaturated fatty acids and is a high-level edible oil ${ }^{2}$. It is also rich in 17 kinds of amino acids and 19 types of essential mineral elements $^{3)}$. The oil of $T$. grandis nut contains a unique fatty acid which is cis-5,10,14-eicosenoic acid (also known as cardamaric acid), which has a noticeable effect on regulating blood lipids and significant role in preventing and treating cardiovascular and cerebrovascular diseases ${ }^{4)}$.

Since the 1980s, T. grandis research mainly focused on plant habitat and growth conditions ${ }^{5)}$, cultivation techniques $^{6)}$, and pest control $^{7)}$, component analysis and nutri- tional value assessments ${ }^{8-11)}$, processing of nuts and oil ${ }^{12,13)}$, and components analysis and utilization of pseudosperm ${ }^{14,15}$ '. In recent years, local governments have been paying more attention to the cultivation and management of $T$. grandis. The cultivated area and the yield of T. grandis has been growing rapidly, but its industrialization level is still relatively low, and the product quality is still a problem. There are problems with product quality which are largely related to improper management and premature harvest. $T$. grandis fruits are usually picked from early to mid-September when the color of fruit surface changes from emerald green to light yellow and longitudinal cracks appeared on the fruit surface. But in reality, the producers usually harvest earlier because of the difficulties in finding workers, land construction, and the climate conditions during optimal harvest times make harvest difficult. In addition, mixing types also leads to an earlier harvest. There are few unmixed gardens in our country. Therefore, the

*Correspondence to: Xiaohua Yao, Research Institute of Subtropical Forestry, Chinese Academy of Forestry (CAF), Hangzhou, ZJ 311400, CHINA

E-mail: yaoxh168@163.com

Accepted November 2, 2020 (received for review June 5, 2020)

Journal of Oleo Science ISSN 1345-8957 print / ISSN 1347-3352 online

http://www.jstage.jst.go.jp/browse/jos/ http://mc.manusriptcentral.com/jjocs 
producers prefer to pick the fruits all at once to reduce the harvest costs. In these cases, harvest time is suitable for some varieties but too early for other varieties.

It is known that early harvest induces significant quality and weight losses ${ }^{16)}$, harvesting too late can make collecting seeds difficult, and mildew creates conditions whereby the nuts easily crack and fall to the ground which threatens quality and safety ${ }^{17}$. It is vital to properly time the fruit harvest to obtain high nut quality and yield ${ }^{18)}$. Compared with camellia (Camellia oleifera Abel.), olive(Olea europaea L.), walnut(Juglans regia L.), and other woody oil species, the research on the harvesting and maturation of T. grandis is minimal. There are no reports about the fruit traits, accumulation of oil content and nutrients at the different harvest periods.

Determination of the optimal fruit-ripening stage for the production of $T$. grandis nut represents a critical choice based on the best combination of quantity and quality. Usually, the optimum harvest time of nuts varies by years, depending on ecological conditions. Accordingly, determination of harvest time should be made by phenological observation. The quite flushing of husks, efficient rotation of fruit in the husk, taking its color of hard shell, and the dropping of nuts (about 3/4 rate) when shaken indicate the optimum harvest time for nuts ${ }^{18,19)}$. As $T$. grandis ripening proceeds, nut characteristics such as weight, kernel rate, oil content, profiles of various phytochemicals, including fatty acids, protein, starch, soluble sugar, tocopherol and total reducing capacity, are changing. These changes influence the chemical composition and qualities of $T$. grandis nut and its oil ${ }^{20)}$. This study evaluates the influence of harvest timing on $T$. grandis nutrient quality and identifies the optimal time for harvest, thereby providing a reference and a guide for actual production.

\section{Materials and Methods}

\subsection{Sampling site}

The study site was located in Fuyang $\left(30^{\circ} 06^{\prime} N, 119^{\circ} 95^{\prime}\right.$ $E$ ), Zhejiang Province(Southeast China). The region is characterized by mountains and hills (105 $\mathrm{m}$ in altitude). It is a mild rainy region with a sub-tropical humid monsoon climate. Yearly precipitation is $1477.9 \mathrm{~mm}$ (average of 30 years). Monthly mean temperature is $4.3^{\circ} \mathrm{C}$ for January and $28.8^{\circ} \mathrm{C}$ for July (Fig. S1). The agro-climatic data were supplied by the local weather bureau in Fuyang district of Hangzhou.

\subsection{Sampling and processing}

The T. grandis trees were managed and had no nutrient deficiencies or pest damage. 8-year-old trees were selected and labeled in groves. To determine the best harvest time in terms of oil yield and other fruit quality parameters, $T$. grandis fruit samples were harvested by hand five times in 2016: Aug. 25 (mature green stage), Aug. 31, Sept. 6, Sept. 12 and Sept. 18 (ripe fruits with epicarp longitudinal cracks), when the fruit was $30 \%$ mature until fully maturity. Only healthy fruits without any infection or physical damage were used. All the fruits were collected from the same 10 trees with a representative subsample (about 100 g) collected from each tree. Immediately after harvesting, fruits were sealed in plastic bags and transported to the laboratory where they were separated from the hulls, then cleaned nuts-in-shell and dried to $7 \%$ kernel moisture content ${ }^{21)}$ in fan-forced oven at $50^{\circ} \mathrm{C}$, and stored at $-18^{\circ} \mathrm{C}$ before analysis.

\subsection{Methods}

2.3.1 Oil extraction and quality analysis

T. grandis nuts were pressed by a vertical hydraulic oil press (6YY-190, Luoyang, China). The following quality evaluation parameters were tested: the kernel percent, kernel moisture content, kernel oil yield, fatty acid profile, free fatty acids (FFA), peroxide value, reducing capacity, tocopherols, soluble sugar content, starch content and the kinds and contents of free amino acids.

Kernel percent was calculated from the total nut and kernel weights after drying. Kernel moisture was determined by differencing weight before and after drying. Kernel oil content was determined using the Soxhlet method whereby seed samples were finely ground in household food grinder and extracted with petroleum ether (boiling range $30 \sim 60^{\circ} \mathrm{C}$ ) in a B811-Soxhlet apparatus (Buchi, Switzerland) for $8 \mathrm{~h}$ at a constant temperature of $70^{\circ} \mathrm{C}$. Protein, starch and total soluble sugar content were determined according to the procedure described by Wang $^{22)}$. FFA content and peroxide value were carried out following the analytical methods described in ISO (International Organization for Standardization) 660 and 3960, respectively.

\subsubsection{Fatty acid profile}

The fatty acid profile was analyzed by gas chromatography. Methyl esters were prepared in compliance with the standard method to determine the fatty acid profile, and oil was analyzed by GC-2010 plus gas chromatography (Shimadzu, Japan) equipped with a flame-ionization detector (FID) detector. The gas-chromatographic condition used were based on the previous study ${ }^{23)}$. The gas chromatograph is equipped with an autosampler, a split/splitless injector, and a FID. A fused silica capillary column FAMEWAX ( $50 \mathrm{~m}$ length $\times 0.25 \mathrm{~mm}$ i.d. and $0.25 \mu \mathrm{m}$ film thickness, Restek, America) was used. The carrier gas was nitrogen with $2 \mathrm{~mL} / \mathrm{min}$ flow rate, and the temperature of injection block and detector was $220^{\circ} \mathrm{C}$. The GC oven heating was initiated at $150^{\circ} \mathrm{C}$. That temperature was maintained for $1 \mathrm{~min}$ and then increased to $190^{\circ} \mathrm{C}$ (at a rate of $5^{\circ} \mathrm{C} / \mathrm{min}$ ) and those conditions were maintained for 20 
min. The injection volume was $1 \mu \mathrm{L}$, the split ratio was 1:10. Commercial mixtures of fatty acid methyl esters (Sigma Aldrich, Milan, Italy) were used as reference data for the relative retention times. The results were expressed as relative area percent of the total.

2.3.3 Determination of tocopherols

Oil samples weighing $1 \mathrm{~g}$ (to an accuracy of $0.01 \mathrm{~g}$ ) were dissolved with $n$-hexane in a $10-\mathrm{mL}$ brown volumetric flask and filtrated through a $0.22-\mu \mathrm{m}$ PTFE filter for HPLC analysis. Tocopherols were measured using an Agilent 1290 high-performance liquid chromatography (Agilent Technologies, Santa Clara, CA, USA) equipped with a silica column $(250 \times 4.6 \mathrm{~mm}$ i.d., $5 \mu \mathrm{m}$, Waters Co., Milford, MA, USA) and a fluorescence detector (Agilent Technologies Inc., Santa Clara, CA, USA). Mobile phase was $n$-hexane and isopropanol with the volume ratio of 98.5:1.5. The flow rate was $1.2 \mathrm{~mL} / \mathrm{min}$, and the sample size was $10 \mu \mathrm{L}$. The column temperature was $30^{\circ} \mathrm{C}$. The fluorescence detection was operated with the excitation wavelength at $295 \mathrm{~nm}$ and the emission wavelength at $333 \mathrm{~nm}$. The $\alpha-, \beta-, \gamma-$, and $\delta$-tocopherols were identified and quantified by comparing with the standards (MilliporeSigma, Billerica, MA). The results were expressed as milligrams of tocopherol per 100 gram of oil.

\subsubsection{Reducing capacity assay}

Folin-Ciocalteu reagent has a meaningful disadvantage since the reacting not only with the phenolic compounds but also with vitamin $\mathrm{C}$, some amino acids, peptides, reduction sugars, organic acids, Maillard reaction products and some more compounds, therefore several researchers advise to interpret obtained results as reducing capacity instead of total phenolics content ${ }^{24,25)}$. The Folin-Ciocalteu method was used to measure sample reducing capacity in the research as reported by Mahmood Ghasemnezhad et $a l .{ }^{26)}$ with some variations. The extracting solution was prepared by solid-liquid extraction using ground kernels $(5 \mathrm{~g})$ and methanol-water $(30: 70, \mathrm{v} / \mathrm{v}, 50 \mathrm{~mL})$ at $70^{\circ} \mathrm{C}$ for three times. $1 \mathrm{~mL}$ of extract was added to $5 \mathrm{~mL}$ of Folin-Ciocalteu's phenol reagent $(5 \% \mathrm{w} / \mathrm{v})$ and to $4 \mathrm{~mL}$ of sodium carbonate $(7.5 \% \mathrm{w} / \mathrm{v})$. The mixture was kept in the dark for 30 min after 1 min of vortex oscillation. Finally, the absorptions of the solution at $765 \mathrm{~nm}$ were measured. Reducing capacity were expressed as mg gallic acid/g of kernel.

\subsubsection{Determination of free amino acids}

The composition and contents of free amino acid in $T$. grandis nut were determined using L-8800 Amino Acid Analyzer (Hitachi, Japan) as reported by Mo R.H. et al. ${ }^{277}$.

All analyses were performed at least in triplicate except where there was insufficient equipment capacity, in which case appropriate repeat analyses were performed.

\subsection{Statistical analysis}

All data were processed and analyzed by Microsoft Office Excel 2010 and SPSS 19.0 statistical software. Results were tested for statistical significance by one-way ANOVA. Differences were considered statistically significant at the $p<0.05$ level.

\section{Results and Discussion}

\subsection{The kernel moisture, kernel yield and oil content un- der different harvesting times}

The quality and economic indicators of $T$. grandis fruits at different harvest timepoints were determined (Table 1). The results showed that the kernel moisture content, kernel yield and oil content of $T$. grandis were significantly different $(p<0.01)$, which indicated that the fruit maturity had a substantial impact on the yield of $T$. grandis nut and its oil. The kernel moisture content decreased from 41.98 $\pm 0.07 \%$ on Aug. 25 to $35.73 \pm 0.09 \%$ on Sept. 12 , and the moisture content further decreased to $30.41 \pm 0.04 \%$ on Sept. 18 which was more than $5 \%$ lower than the moisture value determined six days prior. The kernel yield increased by $1.71 \%$ from Aug. 25 to Sept. 6 , after which time kernel yield did not significantly change $(p>0.05)$. The non-significant differences among harvest dates suggested that the kernels had attained their maximum size before the earliest harvest date (Aug. 25, 2019).

On the contrary, kernel oil content had a substantial increase in the early stages of maturity (before Sept. 6) followed by a significant increase in the latter part of maturation (from $42.32 \%$ on Sept. 6 to $48.4 \%$ on Sept. 18). These data inconsistent were inconsistent with the results obtained by other researchers about grape berry development ${ }^{28,29)}$. Oil content is one of the important indexes to

Table 1 Effect of harvest time on T. grandis nut kernel moisture, kernel yield and kernel oil content.

\begin{tabular}{lccccc}
\hline \multirow{2}{*}{ Indicators } & \multicolumn{5}{c}{ Harvest date } \\
\cline { 2 - 6 } & Aug. 25th & Aug. 31st & Sept. 6th & Sept. 12th & Sept. 18th \\
\hline Kernel moisture content $/ \%$ & $41.98 \pm 0.04 \mathrm{a}$ & $39.41 \pm 0.30 \mathrm{~b}$ & $37.47 \pm 0.03 \mathrm{c}$ & $35.73 \pm 0.06 \mathrm{~d}$ & $30.41 \pm 0.04 \mathrm{e}$ \\
Kernel yield $/ \%$ & $68.84 \pm 0.31 \mathrm{a}$ & $69.80 \pm 0.59 \mathrm{~b}$ & $70.55 \pm 0.40 \mathrm{c}$ & $70.57 \pm 0.44 \mathrm{c}$ & $70.72 \pm 0.40 \mathrm{c}$ \\
Kernel oil content $/ \%$ & $41.75 \pm 0.57 \mathrm{a}$ & $42.19 \pm 0.22 \mathrm{~b}$ & $42.32 \pm 0.14 \mathrm{~b}$ & $43.47 \pm 1.07 \mathrm{c}$ & $48.40 \pm 0.38 \mathrm{~d}$ \\
\hline
\end{tabular}

Note: Kernel yield and kernel oil content expressed as percent of dry weigh. Results are mean \pm standard error. Means with different letters are significantly different $(p<0.05)$. 
evaluate oil plants' quality, and the amount of oil content directly affects economic value of the oil plants. Usually high oil content is associated with high edible quality and good storage stability. Several factors such as cultivar, species, growing conditions, maturity, and extraction method affect plant oil yield ${ }^{28)}$. Previous studies have shown that the crispy taste of $T$. grandis nuts is positively correlated with its oil content ${ }^{3,30)}$. Oil accumulation in fruits increased consistently with postponement of harvest time. This increase may be attributed to continued activity of the triglyceride-forming biosynthesis pathway until the fruit reaches full maturation.

\subsection{Fatty acid profile of nut oil on different harvest date}

The fatty acid profile of oil is its most useful chemical property. The primary fatty acid compositions and contents of oil from the T. grandis nut at the different harvest times is shown in Table 2. The results indicate that T. grandis nut oil was rich in unsaturated fatty acid (UFA) (nearly $90 \%$ of the total fatty acids), especially linoleic acid and oleic acid. High oleic-linoleic oils are of interest because of their superior stability and nutritional importance. Linoleic acid is recognized as one of the most significant polyunsaturated fatty acids (PUFA) in human food because it has preventive effects on heart diseases ${ }^{31,32)}$. T. grandis nut oil also contained higher proportion of cis-5,11,14-eicosatrienoic acid (above 8\%).

In the predominating fatty acid, the oleic acid content increased $(p<0.05)$ with a delay of harvest time from 30.76 $\pm 0.41 \%$ on Aug. 25 to $34.85 \pm 0.45 \%$ on Sept. 18 . Both linoleic acid and cis-5,11,14-eicosatrienoic acid contents decreased between Aug. 25 and Sept. 18, 2019, but there was no significant difference $(p>0.05)$, and there was a negative correlation between the content of oleic acid and linoleic acid. Research has shown that oleic and linoleic acid content are related to maturity or the degree of filling $^{33)}$, and the content of linoleic acid decreases and the oleic acid increases during seed development ${ }^{34)}$. Between Aug. 25 and Sept. 18, 2019, palmitic acid and cis-11,14eicosadienoic acid decreased slightly, while stearic acid increased slightly, but these changes were not significant $(p$ $>0.05)$.

The amounts of fatty acids in the T. grandis nut oil were in the order of PUFA $>$ monounsaturated fatty acid (MUFA) $>$ saturated fatty acid (SFA) for all five harvesting times, this difference was a result of higher levels of linoleic acid and the lower amount of oleic acid in the T. grandis nut oil sample. Total UFAs increased with postponement of harvest time, MUFA were not significant at the beginning of the ripening process of the $T$. grandis fruit (Aug. 25th Aug. 31st) and significant increase at the end (last three points of harvesting, Sept. 6th to Sept. 18th). This is consistent with the results of the author's research group on camellia oil $^{35)}$.

The PUFA constituted over $50 \%$ of the oil, while the MUFA content was relatively lower, ranging from $31.34 \pm$ $0.41 \%$ to $35.44 \pm 0.04 \%$. The SFA content was low (about $11 \%)$ and did not show an apparent change $(p>0.05)$ during ripening. The dietary fats abundant in PUFA can prevent chronic health conditions such as atherosclerosis, coronary heart disease, and high blood pressure. Furthermore, cis-5,11,14-eicosatrienoic acid is a special fatty acid also known as sciadonic acid, which often is found in the leaves and seeds of Gymnosperms, its name comes for its

Table 2 Fatty acid composition and relative content of T. grandis nut oil at different harvest times.

\begin{tabular}{lrrrrr}
\hline \multicolumn{1}{c}{ Fatty acid relative content/\% } & \multicolumn{4}{c}{ Harvest date } \\
\cline { 2 - 6 } & Aug. 25th & Aug. 31st & Sept. 6th & Sept. 12th & Sept. 18th \\
\hline Palmitic acid (C16:0) & $8.66 \pm 0.01 \mathrm{a}$ & $8.58 \pm 0.03 \mathrm{ab}$ & $8.64 \pm 0.03 \mathrm{a}$ & $8.49 \pm 0.02 \mathrm{c}$ & $8.26 \pm 0.01 \mathrm{~d}$ \\
Stearic acid (C18:0) & $2.31 \pm 0.03 \mathrm{a}$ & $2.49 \pm 0.32 \mathrm{~b}$ & $2.71 \pm 0.15 \mathrm{c}$ & $2.95 \pm 0.23 \mathrm{~d}$ & $2.92 \pm 0.03 \mathrm{~d}$ \\
Oleic acid (C18:1) & $30.76 \pm 0.41 \mathrm{a}$ & $30.86 \pm 0.08 \mathrm{a}$ & $32.48 \pm 0.25 \mathrm{~b}$ & $33.87 \pm 0.31 \mathrm{c}$ & $34.85 \pm 0.45 \mathrm{~d}$ \\
Linoleic acid (C18:2) & $43.61 \pm 0.23 \mathrm{a}$ & $43.79 \pm 0.10 \mathrm{~b}$ & $42.82 \pm 0.31 \mathrm{c}$ & $41.58 \pm 0.48 \mathrm{~d}$ & $41.13 \pm 0.48 \mathrm{e}$ \\
Linolenic acid (18:3) & $0.46 \pm 0.07 \mathrm{a}$ & $0.45 \pm 0.03 \mathrm{~b}$ & $0.45 \pm 0.03 \mathrm{c}$ & $0.44 \pm 0.03 \mathrm{~d}$ & $0.45 \pm 0.22 \mathrm{e}$ \\
Eicosanoic acid (C20:0) & $0.12 \pm 0.00 \mathrm{a}$ & $0.17 \pm 0.04 \mathrm{a}$ & $0.13 \pm 0.00 \mathrm{a}$ & $0.14 \pm 0.00 \mathrm{a}$ & $0.13 \pm 0.03 \mathrm{a}$ \\
cis-11-eicosenoic acid (C20:1) & $0.57 \pm 0.03 \mathrm{a}$ & $0.55 \pm 0.07 \mathrm{ab}$ & $0.55 \pm 0.07 \mathrm{ab}$ & $0.57 \pm 0.00 \mathrm{ab}$ & $0.59 \pm 0.06 \mathrm{~b}$ \\
cis-11,14-eicosadienoic acid (C20:2) & $2.90 \pm 0.05 \mathrm{a}$ & $2.83 \pm 0.21 \mathrm{a}$ & $2.70 \pm 0.12 \mathrm{~b}$ & $2.70 \pm 0.06 \mathrm{bc}$ & $2.71 \pm 0.03 \mathrm{bd}$ \\
cis-5,11,14-eicosatrienoic acid (C20:3) & $9.89 \pm 0.07 \mathrm{a}$ & $9.46 \pm 0.04 \mathrm{~b}$ & $8.98 \pm 0.01 \mathrm{c}$ & $8.66 \pm 0.03 \mathrm{~d}$ & $8.35 \pm 0.14 \mathrm{e}$ \\
Unsaturated fatty acid (UFA) & $85.54 \pm 0.49 \mathrm{a}$ & $85.78 \pm 0.16 \mathrm{a}$ & $87.92 \pm 0.55 \mathrm{~b}$ & $90.03 \pm 0.08 \mathrm{c}$ & $90.84 \pm 0.14 \mathrm{~d}$ \\
$\quad$ Monounsaturated fatty acid (MUFA) & $31.34 \pm 0.41 \mathrm{a}$ & $31.43 \pm 0.08 \mathrm{a}$ & $32.97 \pm 0.02 \mathrm{~b}$ & $34.44 \pm 0.03 \mathrm{c}$ & $35.44 \pm 0.04 \mathrm{~d}$ \\
$\quad$ Polyunsaturated fatty acid (PUFA) & $54.20 \pm 0.34 \mathrm{a}$ & $54.35 \pm 0.13 \mathrm{a}$ & $54.95 \pm 0.54 \mathrm{a}$ & $55.59 \pm 0.11 \mathrm{ab}$ & $55.40 \pm 0.10 \mathrm{ac}$ \\
Saturated fatty acid (SFA) & $11.09 \pm 0.01 \mathrm{a}$ & $11.24 \pm 0.06 \mathrm{~b}$ & $11.48 \pm 0.05 \mathrm{c}$ & $11.57 \pm 0.01 \mathrm{~cd}$ & $11.33 \pm 0.01 \mathrm{be}$ \\
\hline
\end{tabular}

Note: Results are mean \pm standard error. Means with different letters are significantly different $(p<0.05)$. 
rich in a plant of Sciadopitys verticillata (golden pine) in Japan $^{36)}$. Previous research showed that sciadonic acid presents a strong role in lipid regulation in rats. Moreover, sciadonic acid could inhibit the activity of fatty acid synthase and 6-phosphate glucose dehydrogenase in liver and plasma of $\operatorname{rats}^{37,38)}$. Thus, based on the contents of PUFA and sciadonic acid, the oil from $T$. grandis nuts is a higher nutritional and functional edible oil, and has a great value for exploitation and utilization. The fatty acid composition of seed oils varies widely among different plant species, and often the occurrence of unusual fatty acids can be used for the differentiation of particular plant families ${ }^{39)}$. Therefore, sciadonic acid can also be used as an essential fatty acid to distinguish $T$. grandis oil from other plant oils.

\subsection{FFA and peroxide value on different harvest time}

FFA and peroxide value are important indexes to evaluate the quality of oil plants. The amounts of FFA and peroxide value in $T$. grandis nut oil at different fruit maturity times were analyzed (Fig. 1). The effect of harvesting time on the FFA and peroxidation value were significant $(p<$ $0.05)$, with both factors declining with delayed harvesting time. This result was consistent with previous research on camellia seeds $^{17)}$. The FFA and peroxide value of $T$. grandis sharply decreased from $0.39 \pm 0.06 \mathrm{mg} / \mathrm{g}$ and 2.92 $\pm 0.30 \mathrm{~g} / 100 \mathrm{~g}$ at first harvest to $0.23 \pm 0.02 \mathrm{mg} / \mathrm{g}$ and 0.70 $\pm 0.41 \mathrm{~g} / 100 \mathrm{~g}$ at the last harvest, respectively. Combined with the fact that riper $T$. grandis fruits have higher oil content, we could draw the conclusion that more FFA in cell tissues are used to synthesize triglyceride as $T$. grandis fruit matures, which leads to the decrease of FFA This result is consistent with prior study ${ }^{40)}$. Also, ripening fruits contained more antioxidants that entered the oil, thereby reducing the oxidation of the oil to some extent ${ }^{41)}$.

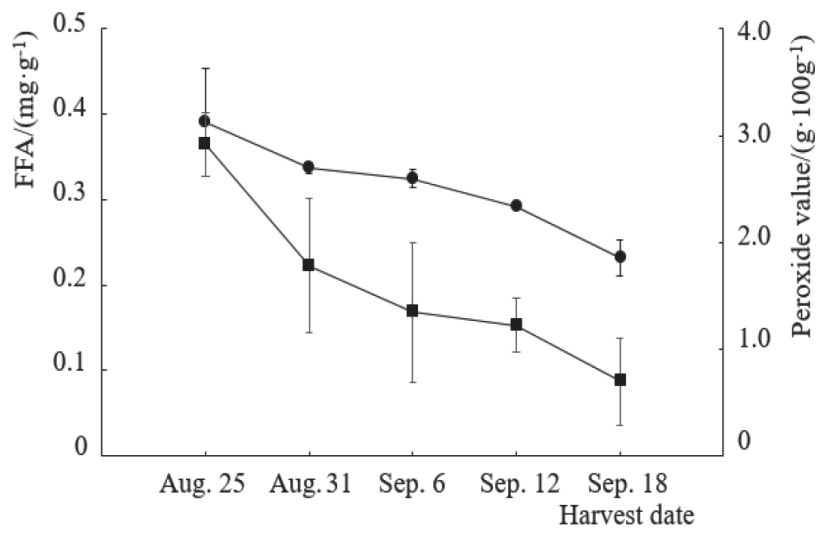

Fig. 1 FFA $(\bigcirc)$ and peroxide value $(\square)$ of $T$. grandis nut at different harvest times.

\subsection{Protein, soluble sugar and starch contents on differ- ent harvest times}

Protein is one of the main nutritional components in $T$. grandis nuts, and starch and soluble sugar are the standard indexes to evaluate the quality of oil seed. With the $T$. grandis fruit maturing, the protein content in its nut increased $(p<0.05)$ from $23.3 \pm 0.08 \%$ on Aug. 25 to $25.3 \pm$ $0.12 \%$ on Sept. 18. As shown in Fig. 2, there were no significant differences in terms of starch and soluble sugar amounts for different harvest times $(p>0.05)$. The soluble sugar content was $4.24 \pm 0.03 \%$ on Aug. 25 , and then it increased to $6.06 \pm 0.32 \%$ on Sept. 18 with the delay of harvest time. On the contrary, the starch content dropped from $5.95 \pm 0.21 \%$ on Aug. 25 to $5.50 \pm 0.07 \%$ on Sept. 18 . It was interesting that the increased in soluble sugar content coincided with a decline in starch content during ripening; the two factors were negatively correlated $(r=$ $-0.8773,95 \% \mathrm{CI}=-0.718 \sim-1.000, p=0.05)$, which suggesting that the increased soluble sugar mainly came from the hydrolysis of starch.

\subsection{The composition and content of tocopherol on differ- ent harvest times}

Tocopherol is an important natural antioxidant, which can effectively block free radical chain reactions, prevent and reduce lipid peroxidation damage of cell membranes to protect cell membranes, remove free radicals and prevent cancer in vivo ${ }^{42)}$. It is present in plants in four forms which possess different molecular structures and functions: $\alpha-$, $\beta$-, $\gamma$ - and $\delta$-, of which $\alpha$-tocopherol has the strongest physiological activity.

The tocopherol composition and contents of T. grandis nut collected at the different maturation dates are presented in Table 3. $\alpha$-tocopherol and $\beta$-tocopherol were identified from $T$. grandis nut, the content of $\beta$-tocopherol (more than $100 \mathrm{mg} / 100 \mathrm{~g}$ ) was about four times higher than

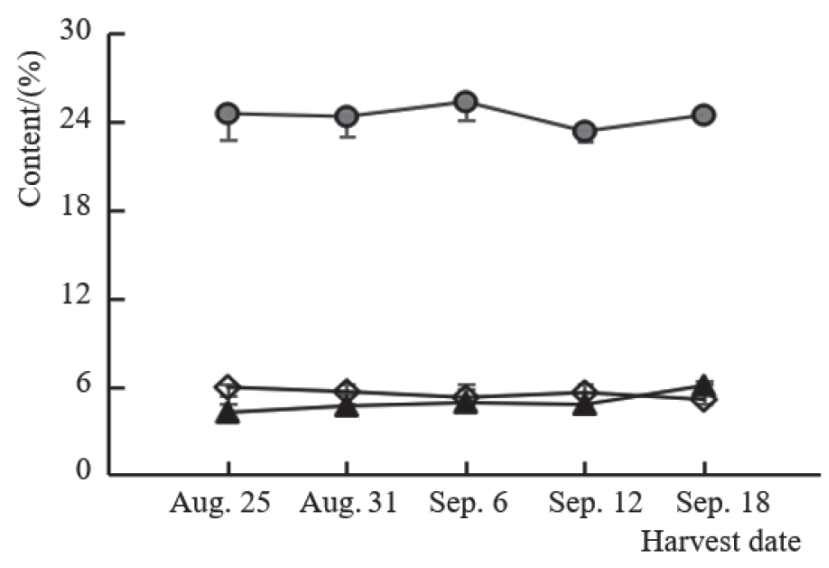

Fig. 2 Protein $(\boldsymbol{O})$, soluble sugar $(\boldsymbol{\Delta})$ and $\operatorname{Starch}(\diamond)$ content of $T$. grandis nut at different harvest times. 
Y. Wang, X. Yao, L. Yang et al.

Table 3 Tocopherols composition and content in T. grandis nut at different harvest times.

\begin{tabular}{cccccc}
\hline \multirow{2}{*}{ Content $/\left(\mathrm{mg} \cdot 100 \mathrm{~g}^{-1}\right)$} & \multicolumn{5}{c}{ Harvest date } \\
\cline { 2 - 6 } & Aug. 25th & Aug. 31st & Sep. 6th & Sep. 12th & Sep. 18th \\
\hline$\alpha$-tocopherol & $23.45 \pm 0.05 \mathrm{a}$ & $24.67 \pm 0.03 \mathrm{~b}$ & $24.48 \pm 0.02 \mathrm{c}$ & $25.39 \pm 0.01 \mathrm{~d}$ & $26.15 \pm 0.05 \mathrm{e}$ \\
$\beta$-tocopherol & $103.95 \pm 0.05 \mathrm{a}$ & $105.96 \pm 0.05 \mathrm{~b}$ & $108.97 \pm 0.10 \mathrm{c}$ & $111.18 \pm 0.15 \mathrm{~d}$ & $111.52 \pm 0.10 \mathrm{de}$ \\
$\gamma$-tocopherol & $N D$ & $N D$ & $N D$ & $N D$ & $N D$ \\
$\delta$-tocopherol & $N D$ & $N D$ & $N D$ & $N D$ & $N D$ \\
Total tocopherol & $127.5 \pm 0.04 \mathrm{a}$ & $130.7 \pm 0.36 \mathrm{~b}$ & $133.5 \pm 0.30 \mathrm{c}$ & $136.4 \pm 0.05 \mathrm{~d}$ & $137.1 \pm 0.02 \mathrm{de}$ \\
\hline
\end{tabular}

Note: $N D$, not detectable. Results are mean \pm standard error. Means with different letters are significantly different $(p<0.05)$.

$\alpha$-tocopherol (when concentrations are above $23 \mathrm{mg} / 100$ g), but no $\gamma$-tocopherol and $\delta$-tocopherol had been detected, which is consistent with previous study ${ }^{4)}$. The total tocopherol contents gradually increased from $127.5 \pm 0.04$ $\mathrm{mg} / 100 \mathrm{~g}$ on the first date to $137.1 \pm 0.02 \mathrm{mg} / 100 \mathrm{~g}$ on the last date. The levels of $\alpha$-tocopherol and $\beta$-tocopherol increased with ripening, and reached the highest values at Sept. 18, which increased $11.51 \%$ and $7.28 \%$ from the first fruit picking respectively. Besides the influence of the harvest time, also other factors should be taken into account. For instance, in acorns, genotype and the year have a significant impact on the concentration of tocopher$\mathrm{ols}^{43}$. Commonly, plant seeds are rich in homologues $\alpha$ and $\gamma$ - but little or no $\beta$ - and $\delta^{-44)}$, but T. grandis nut oil is rich in $\beta$-tocopherol. There was rarely reported about the predominance of $\beta$-tocopherol on other plants, only in last decade some meaning reports in acorns ${ }^{43)}$, coffee beans ${ }^{44)}$, wheat germ ${ }^{45)}$, apple seeds ${ }^{46)}$, European cranberrybush seeds $^{47)}$, kerkir seeds ${ }^{48}$ had been published. Therefore, in $T$. grandis $\beta$-tocopherol is a main tocopherol homologue which can serve as a characteristic indicator of $T$. grandis nut oil. It can be used as an unconventional natural source of the rare tocopherol homologue.

\subsection{The reducing capacity on different harvest times}

The antioxidant activity of a substance is directly related to its reducing capacity. The stronger the reducing capacity is, the stronger the antioxidant activity. Therefore, the antioxidant activity of a substance can be illustrated by measuring its reducing capacity. Figure 3 lists the reducing capacity in the T. grandis nuts harvested at the five harvest dates. The results showed that the reducing capacity initially increased reaching a peak value of $17.87 \pm 0.03 \mathrm{mg} / \mathrm{g}$ on Sept. 6, then declined gradually during the later ripening stages, though values were still higher than the initial value. With the harvest time delay, the color of $T$. grandis aril changed from light red to crimson which might be related to oxidation of phenols; phenols were oxidized to quinones which could be polymerized to produce colored substances that caused tissue browning ${ }^{49)}$. The degree of browning is usually positively correlated with the content of phenols. This falling of reducing capacity at the late

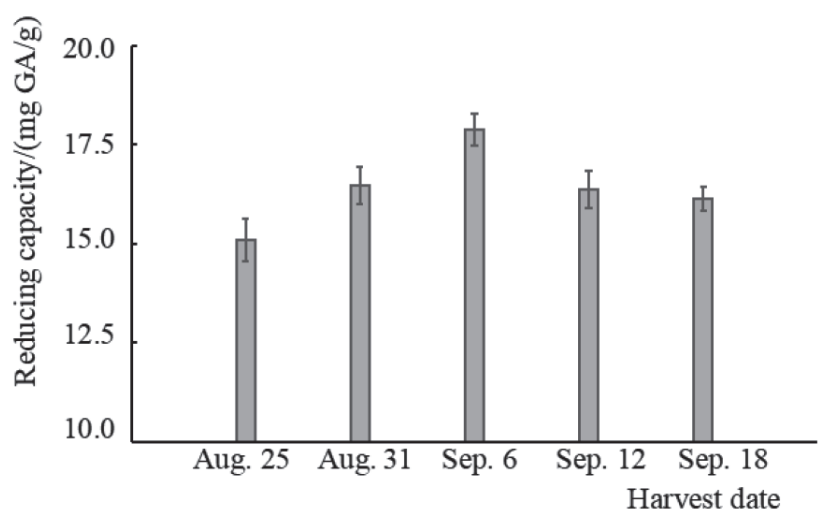

Fig. 3 The reducing capacity in $T$. grandis nuts at different harvest times.

harvest date was mainly attributed to the decline in astringent substance, for example, phenolic substances occurring as part of the physiological maturation of the fruits ${ }^{18}$. In addition, the content of phenolic substances in fruits is closely related to the edible qualities of fruits such as texture, fragrance and astringent and bitter taste ${ }^{50)}$. The higher level of phenolics could bring strong astringency, which affected the taste and flavor of the T. grandis nuts. But at the same time, phenolic compounds can raise the stability, sensory and health properties of oil, the amount of which was an important factor affecting the quality of $\mathrm{oil}^{20)}$. It is known that the content of antioxidant compounds in plant materials such as phenolics varies greatly with, for example, processing, genotype, harvest time, growing environment and conditions.

\subsection{Effects of harvest time on free amino acids}

Amino acids are the primary composition unit of protein and the decomposition product of protein, which are also one of the components of fruit quality and participate in the synthesis of other quality characteristic components and flavor substances ${ }^{51}$. Since the content of free amino acids is closely related to food processing and food flavor, we studied the composition and content of free amino acid in the T. grandis nut. Table 4 shows that there were 17 free amino acids in the $T$. grandis nut, the total content of 
Table 4 The free amino acid composition and content in T. grandis nut with different harvest times.

\begin{tabular}{|c|c|c|c|c|c|}
\hline \multirow{2}{*}{ Content $/ \%$} & \multicolumn{5}{|c|}{ Harvest date } \\
\hline & Aug. 25th & Aug. 31st & Sept. 6th & Sept. 12th & Sept. 18th \\
\hline Aspartic acid & $0.52 \pm 0.22 \mathrm{c}$ & $0.32 \pm 0.01 b$ & $0.30 \pm 0.08 b$ & $0.60 \pm 0.02 \mathrm{a}$ & $0.18 \pm 0.03 d$ \\
\hline Threonine* & $0.38 \pm 0.11 \mathrm{a}$ & $0.35 \pm 0.01 \mathrm{a}$ & $0.34 \pm 0.10 \mathrm{a}$ & $0.61 \pm 0.07 b$ & $0.75 \pm 0.01 \mathrm{c}$ \\
\hline Serine & $0.46 \pm 0.05 \mathrm{a}$ & $0.47 \pm 0.02 \mathrm{a}$ & $0.67 \pm 0.07 b$ & $1.45 \pm 0.27 \mathrm{c}$ & $1.54 \pm 0.06 \mathrm{~d}$ \\
\hline Glutamate & $1.26 \pm 0.31 \mathrm{a}$ & $1.27 \pm 0.23 \mathrm{a}$ & $1.40 \pm 0.28 b$ & $1.72 \pm 0.18 \mathrm{c}$ & $1.95 \pm 0.39 \mathrm{~d}$ \\
\hline Glycine & $0.75 \pm 0.24 d$ & $0.60 \pm 0.17 \mathrm{a}$ & $0.61 \pm 0.13 \mathrm{a}$ & $0.69 \pm 0.11 \mathrm{c}$ & $0.66 \pm 0.09 b$ \\
\hline Alanine & $0.78 \pm 0.28 \mathrm{a}$ & $0.83 \pm 0.24 \mathrm{a}$ & $0.76 \pm 0.02 \mathrm{a}$ & $1.34 \pm 0.41 b$ & $1.55 \pm 0.44 \mathrm{c}$ \\
\hline Valine* & $1.08 \pm 0.37 \mathrm{a}$ & $1.10 \pm 0.02 \mathrm{a}$ & $1.16 \pm 0.56 b$ & $1.14 \pm 0.02 b$ & $1.28 \pm 0.06 \mathrm{c}$ \\
\hline Cystine & $0.14 \pm 0.01 \mathrm{c}$ & $0.16 \pm 0.05 \mathrm{~d}$ & $0.12 \pm 0.27 b$ & $0.12 \pm 0.05 b$ & $0.09 \pm 0.31 \mathrm{a}$ \\
\hline Methionine* & $0.26 \pm 0.11 \mathrm{a}$ & $0.23 \pm 0.01 \mathrm{a}$ & $0.33 \pm 0.06 b$ & $0.26 \pm 0.03 a$ & $0.35 \pm 0.00 b$ \\
\hline Isoleucine* & $0.97 \pm 0.23 \mathrm{~d}$ & $0.82 \pm 0.12 \mathrm{c}$ & $0.76 \pm 0.01 b$ & $0.75 \pm 0.32 b$ & $0.61 \pm 0.02 \mathrm{a}$ \\
\hline Leucine* & $1.19 \pm 0.06 b$ & $1.30 \pm 0.31 \mathrm{c}$ & $1.43 \pm 0.22 \mathrm{~d}$ & $1.14 \pm 0.25 b$ & $0.95 \pm 0.07 \mathrm{a}$ \\
\hline Tyrosine & $1.31 \pm 0.03 \mathrm{a}$ & $1.37 \pm 0.09 \mathrm{a}$ & $2.10 \pm 0.30 b$ & $2.80 \pm 0.31 \mathrm{c}$ & $3.40 \pm 0.12 \mathrm{~d}$ \\
\hline Phenylalanine* & $1.30 \pm 0.19 \mathrm{a}$ & $1.45 \pm 0.21 b$ & $1.75 \pm 0.35 c$ & $1.92 \pm 0.09 c$ & $2.19 \pm 0.32 \mathrm{~d}$ \\
\hline Lysine* & $0.50 \pm 0.32 \mathrm{a}$ & $0.79 \pm 0.13 b$ & $0.74 \pm 0.15 b$ & $0.93 \pm 0.24 \mathrm{c}$ & $0.96 \pm 0.08 \mathrm{c}$ \\
\hline Histidine & $0.35 \pm 0.08 \mathrm{c}$ & $0.23 \pm 0.06 b$ & $0.21 \pm 0.02 b$ & $0.25 \pm 0.14 b$ & $0.12 \pm 0.04 a$ \\
\hline Arginine & $0.69 \pm 0.10 b$ & $1.39 \pm 0.11 \mathrm{c}$ & $0.41 \pm 0.01 \mathrm{a}$ & $0.63 \pm 0.13 b$ & $1.43 \pm 0.09 \mathrm{c}$ \\
\hline Proline & $0.44 \pm 0.06 \mathrm{a}$ & $0.44 \pm 0.07 \mathrm{a}$ & $0.26 \pm 0.07 b$ & $0.20 \pm 0.10 \mathrm{~b}$ & $0.22 \pm 0.05 b$ \\
\hline Total amino acid & $12.38 \pm 0.27 \mathrm{a}$ & $13.12 \pm 0.37 b$ & $13.35 \pm 0.13 b$ & $16.55 \pm 0.43 c$ & $18.23 \pm 0.43 \mathrm{~d}$ \\
\hline
\end{tabular}

Note: *, essential amino acids. Results are mean \pm standard error. Means with different letters are significantly different $(p<0.05)$.

these free amino acids is more than $12 \%$, among which the contents of tyrosine, phenylalanine, glutamate and valine were higher than $1 \%$. Humans require seven types of amino acids that we cannot naturally synthesis: threonine, valine, methionine, leucine, isoleucine, phenylalanine and lysine. In our analysis, tyrosine content was highest in the T. grandis nut, while the content of histidine was the lowest. With the delay in harvesting time, the content of all essential amino acids except isoleucine and leucine showed an upward trend.

Amino acid compositions are nutritionally important and are influence the taste of plant fruits ${ }^{52)}$. Amino acids which have flavor properties can be divided into sweet (e.g. glycine, alanine, serine, threonine, proline, histidine and glutamine), bitter (e.g. valine, leucine, isoleucine, methionine, tryptophan and arginine) and delicious (e.g. lysine, glutamine, aspartic acid and asparagine) and aromatic amino acids (e.g. phenylalanine, tyrosine and cysteine) ${ }^{53)}$. As shown in Fig. 4, among the flavor amino acids in $T$. grandis nuts, the content of sweet amino acids and aromatic amino acids were relatively high (more than $30 \%$ and $20 \%$ of the total free amino acids, respectively). Both the sweet and aromatic amino acids showed rapid increases during the early stage from $4.42 \%$ and $2.75 \%$ on Aug. 25 to $6.79 \%$ and $5.68 \%$ on Sept. 18 , respectively. By contrast,

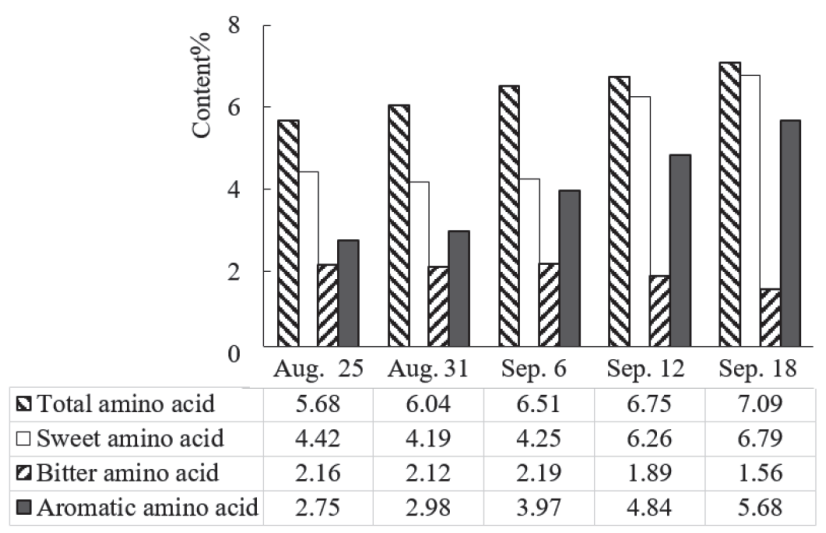

Fig. 4 The free amino acid types in T. grandis nuts at different harvest times. Values are mean and standard error.

the content of bitter amino acids decreased with the delay of picking time and drop more slowly early (from Aug. 25 to Sept. 6), since then it has fallen rapidly to $1.56 \%$. These results indicate that a late harvest times is beneficial to the flavor of $T$. grandis nuts.

These results were in agreement with previous research that there was an improvement in flavor quality of pecans after they reached full size, but that the flavor was subject 
to impairment, mostly through the onset on oxidation, staleness and rancidity ${ }^{54)}$.

\section{Conclusion}

The study showed that $T$. grandis nuts were a rich source of tocopherols, mainly homologue $\beta$-tocopherol. which was a unique finding, due to previous studies often reporting low abundance of this homologue in other plant materials. Therefore, T. grandis nut can be used as an unconventional natural resource of the rare tocopherol homologue.

Based on the results of different harvest time in this study, we concluded that the kernel yield of T. grandis had no clear change in later harvesting. With the exception of moisture, protein, and starch contents, the content levels of most analytes increased with prolonged ripening time, reaching their highest values on Sept. 18. The acid values and peroxide values declined with prolonged ripening time, and reached their lowest values at Sept. 18. This showed that $T$. grandis kernels were no longer gaining weight, but their nutrients were still accumulating, and at that point, their nutrition and quality indicators were high. Therefore, prolonged ripening is helpful to the accumulation of dry matter and nutrients in T. grandis nuts. This results are helpful for the choosing suitable harvest time for $T$. grandis fruit to maximize their beneficial effects for human health.

\section{Conflicts of Interest}

The authors have no conflicts of interest to declare.

\section{Acknowledgments}

The present study was supported by the Science and Technology Project of Zhejiang Province (Grant Number 2018C02006) and Forestry Industrial Standard Project (Grant Number 2018-LY-146).

\section{Supporting Information}

This material is available free of charge via the Internet at http://dx.doi.org/jos.70.10.5650/jos.ess20155

\section{References}

1) Dai, Z.; Chen, L.G.; Tong, P.Z. Genetic variation and fingerprinting of Torreya grandis cultivars detected by ISSR markers. Acta Hort. Sinica. 35, 1125-1130 (2008).

2) Li, Z.J.; Dai, W.S. (eds). Chinese torreya. $1^{\text {st }}$ ed. Science Press, Beijing, pp. 7-15(2007).

3) Li, Z.J.; Luo, C.F.; Chen, X.J.; Feng, X.J.; Yu, W.W. Component analysis and nutrition evaluation of seeds of Torreya grandis 'Merrillii'. J. Zhejiang Forestry 22, 540-544(2005).

4) Mao, J.H.; Zhao, C.W.; Wang, J.F.; Zhou, Y.C.; Tian, H.; Jin, Q.Z. Structural identification of sciadonic acid and component analysis of Torreya grandis seed oil. China Oils \& Fats 42, 135-139(2017).

5) Huang, Q.Y.; Wang, F.G.; Zhao, Y.J.; Li, R.F.; Hu, Y.Y.; Zhang, C.M. Effect of boron, zinc, copper and molybdenum fertilizers on plant growth, nut yield and quality in Torreya grandis. Non-wood Forest Res. 3, 33-38(2015).

6) Wang, L.H. Biological characteristics of Torreya grandis cultivars and the application of efficient cultivation techniques. Flowers 6, 67-68(2016).

7) Zhang, S.Y.; Li, L.; Chen, X.L.; Qi, Q.Q.; Lou, H.Z.; Zhang, C.Q. Identification of brown spot on fruit of Torreya grandis and screening of fungicides. Acta Phytoph. Sin. 44, 817-825(2017).

8) Wang, Y.B.; Liu, B.T.; Qin, Y.C.; Wang, L.L.; Tong, P.Z.; Qian, H. Compositions of fatty acid and flavor compounds in different cultivars of Torreya grandis seed oil. China Oils \& Fats 41, 101-105 (2016).

9) Wu, F.; Han, Q.; Yu, Y.J.; Ni, S. GC-MS analysis of fatty acids from Torreya grandis and Camellia oleifera seed. Chin. Wild Plant Resources 33, 36-39 (2014).

10) Wang, H.; Guo, T.; Ying, G.Q. Advances in studies on active constituents and their pharmacological activities for plants of Torreya Arn. Chin. Tradit. Herb Drugs 38, 1747-1750(2007).

11) Xu, C.; Wang, H.F.; Shao, X.F.; Yu, W.W. Study on antioxidant activity and reducing blood fat function of Kaga Oil. J. Chin. Cereal Oil Assoc. 27, 43-47(2012).

12) Ni, Q.X.; Gao, Q.X.; Yu, W.W.; Liu, X.Q.; XU, G.Z.; Zhang, Y.Z. Supercritical carbon dioxide extraction of oils from two Torreya grandis varieties seeds and their physicochemical and antioxidant properties. Food Sci. Technol. 60, 1226-1234(2015).

13) He, Z.Y.; Zhu, H.D.; Li, W.L.; Zeng, M.M.; Wu, S.F.; Chen, S.W. Chemical components of cold pressed kernel oils from different Torreya grandis cultivars. Food Chem. 209, 196-202 (2016).

14) Wang, Y.; Guo, L.; Yu, Y.; Chen, X.; Ding, Z.E. Analysis of aroma components in Torreya grandis by static headspace-GC/MS. J. Chin. Cereal Oil Assoc. 29, 116-121 (2014).

15) Niu, L.Y.; Bao, J.F.; Zhao, L.; Zhang, Y. Odor properties and volatile compounds analysis of Torreya grandis Aril extracts. J. Essent. Oil Res. 23, 1-6(2011). 
16) Baccouri, B.; Temime, S.B.; Taamalli, W.; Daoud, D.; M’ Sallem, M.; Zarrouk, M. Analytical characteristics of virgin olive oils from two new varieties obtained by controlled crossing on Meski variety. Food Lipids 14, 19-34 (2007).

17) Wang, Y.P.; Fei, X.Q.; Shi, X.L.; Ye, X.F.; Guo, S.H.; Luo, F. Effects of harvest time and treatment methods on nutrient accumulation of oil-tea camellia seed and its oil. China Oils \& Fats 42, 20-23, 46 (2017).

18) Ozgun, K.; Ali, T.; Zuhal, O.; Duygu, O. Evaluation of the effect of different harvest time on the Fruit quality of Foşa nut. Erwerbs-Obstbau 58, 89-92 (2016).

19) Koksal, A.I.; Gunes, N.T.; Belge, B. The effect of sampling year and geographical regions on some physical characteristics of hazelnut cultivars grown in Turkey. Acta Hortic. 940, 301-307 (2012).

20) Arnon, D.; Guy, H.; Shimon, L.; Isaac, Z.; Zohar, K. Optimizing olive harvest time under hot climatic conditions of Jordan Valley, Israel. Eur. J. Lipid Sci. Technol. 116, 169-176 (2014).

21) Wang, Y.P.; Shi, X.L.; Yao, X.H.; Fei, X.Q.; Guo, S.H.; Luo, F. Suitable moisture content maintaining storage quality of oil-tea camellia seed. Trans. CSAE. 32, 256261 (2016).

22) Wang, Y.H. (ed.) Food analysis, $2^{\text {nd }}$ ed. China light industry press, Beijing, pp. 36-42 (2011).

23) Wang, Y.P.; Fei, X.Q.; Chen, Y.; Luo, F.; Wang, K.L.; Yao, X.H. Effects of oil extracting technique on quality and safety of oil-tea camellia seed oil. J. Chin. Cereal Oil Assoc. 27, 60-63 (2012).

24） Górnaś, P.; Dwieck, K.; Siger, A.; Tomaszewska-Gras, J.; Michalak, M.; Polewski, K. Contribution of phenolic acids isolated from green and roasted boiled-type coffee brews to total coffee antioxidant capacity. Eur. Food Res. Technol. 242, 641-653(2016).

25) Huang, D.J.; Ou, B.X.; Prior, R.L. The chemistry behind antioxidant capacity assays. J. Agric. Food Chem. 53, 1841-1856 (2005).

26) Mahmood, G.; Mohamad, S.; Gholam, A.P. Variation in phenolic compounds, ascorbic acid and antioxidant activity of five coloured bell pepper (Capsicum annum) fruits at two different harvest times. J. Funct. Foods. 3, 44-49 (2011).

27) Mo, R.H.; Tang, F.B.; Ding, M.; Qu, M.H.; Ni, Z.L.; Shen, D.Y. Determination of free amino acids in bamboo shoot by amino acids analyzer. Chem. 75, 1126-1131 (2012).

28) Rubio, M.; Alvarez-Ortí, M.; Alvarruiz, A.S.; Fernández, E.; Pardo, J.E. Characterization of oil obtained from grape seeds collected during berry development. $J$. Agric. Food Chem. 57, 2812-2815(2009).

29) Mišina, I.; Sipeniece, E.; Rudzińska, M.; Grygier, A.; Radzimirska-Graczyk, M.; Kaufmane, E.; Górnaś, P. Associations between oil yield and profile of fatty acids, sterols, squalene, carotenoids and tocopherols in seed oil of selected Japanese quince genotypes during fruit development. Eur. J. Lipid Sci. Technol. 122, $1900386(2020)$.

30) Li, Z.J.; Hua, J.Q.; Zeng, Y.R. Oil content of Camellia oleifera fruit trees. J. Zhejiang A\&F Univ. 27, 935$940(2010)$.

31) Manzoor, M.; Anwar, F.; Ashraf, M.; Alkharfy, K.M. Physico-chemical characteristics of seed oils extracted from different apricot (Prunus armeniaca L.) varieties from Pakistan. Grasas. Aceites. 63, 193-201 (2012).

32) Matthaus, B.; Özcan, M.M.; Juhaimi, F.A. Fatty acid composition and tocopherol content of the kernel oil from apricot varieties (Hasanbey, Hacihaliloglu, Kabaasi and Soganci) collected at different harvest times. Eur. Food Re. Technol. 242, 221-226 (2016).

33) Aguilera, M.P.; Beltrán, G.; Ortega, D.; Fernández, A.; Jiménez, A.; Uceda, M. Characterisation of virgin olive oil of Italian olive cultivars: 'Frantoio' and 'Leccino', grown in Andalusia. Food Chem. 89, 387-391 (2005).

34) Górnaś, P.; Rudzińska, M.; Grygier, A.; Lacis, G. Diversity of oil yield, fatty acids, tocopherols, tocotrienols, and sterols in the seeds of 19 interspecific grapes crosses. J. Sci. Food Agric. 99, 2078-2087 (2019).

35) Cao, Y.Q.; Yao, X.H.; Ren, H.D.; Wang, K.L. Correlation between mineral elements content and oil accumulation in fruits of Camellia oleifera. CSUFT. 33, 38-41 (2013).

36) Blaise, P.; Tropini, V.; Farines, M.; Wolff, R.L. Positional distribution of $\Delta 5$-Acids in triacylglycerols from Conifer seeds as determined by partial chemical cleavage. J. Am. Oil Chem. Soc. 2, 165-168(1997).

37) Endo, Y.; Osada, Y.; Kimura, F.; Fujumoto, K. Effects of Japanese torreya (Torreya nucifera) seed oil on lipid metabolism in rats. Nutri. 22, 553-558(2006).

38) Endo, Y.; Tsunokake, K.; Ikeda, I. Effect of non-methylene-interrupted polyunsaturated fatty acid, sciadonic (all-cis-5,11,14-eicosatrienoic acid) on lipid metabolism in rats. Biosci. Biotechnol. Biochem. 73, 577581 (2009).

39) Aitzetmüller, K. Capillary GLC fatty acid fingerprints of seed lipids-a tool in plant chemotaxonomy. J. High Resolut. Chromatogr. 16, 488-490 (1993).

40) Morelló, J.R.; Romero, M.P.; Motilva, M.J. Effect of the maturation process of the olive fruit on the phenolic fraction of drupes and oils from Arbequina, Farga, and Morrut cultivars. J. Agric. Food Chem. 52, 6002-6009 (2004).

41) Xu, L.; Wang, R.L.; Cao, X.B.; Li, H.Y.; Zheng, Y. Study on the variation of anti-oxidates in olive oil. J. Henan Univ. Techno. (Nat Sci Ed) 28, 38-41 (2007).

42) Song, X.Y.; Yang, T.K. Functions and applications of natural vitamin E. China Oil \& Fat 25, 45-47 (2000). 
43) Górnaś, P. Oak Quercus rubra L. and Quercus robur L. acorns as an unconventional source of gamma- and beta-tocopherol. Eur. Food Res. Technol. 245, 257261 (2019).

44) Górnaś, P.; Pugajeva, I.; Segliṇa, D. Seeds recovered from by-products of selected fruit processing as a rich source of tocochromanols: RP-HPLC/FLD and RPUPLC-ESI/MSn study. Eur. Food Res. Technol. 239, 519-524(2014).

45) Górnaś, P.; Siger, A.; Polewski, K.; Pugajeva, I.; Waśkiewicz, A. Factors affecting tocopherol contents in coffee brews: NP-HPLC/FLD, RP-UPLC-ESI/MSn and spectroscopic study. Eur. Food Res. Technol. 238, 259-264(2014).

46) Fromm, M.; Bayha, S.; Kammerer, D.R.; Carle, R. Identification and quantitation of carotenoids and tocopherols in seed oils recovered from different Rosaceae species. J. Agric. Food Chem. 60, 10733-10742 (2012).

47) Kraujalis, P.; Kraujalienè, V.; Kazernavičiūtè, R.; Venskutonis, P.R. Supercritical carbon dioxide and pressurized liquid extraction of valuable ingredients from $\mathrm{Vi}$ burnum opulus Pomace and berries and evaluation of product characteristics. J. Supercrit. Fluids 122, 99-108 (2017).

48) Mariod, A.A.; Elkheir, S.; Ahmed, Y.M.; Matthäus, B.
Annona squamosa and Catunaregam nilotica seeds, the effect of the extraction method on the oil composition. J. Am. Oil Chem. Soc. 87, 763-769 (2010).

49) Wang, Y.; Wu, G.L.; Xu, Y.G.; Yan, F.J. Diversification of the phenols contents in walnuts fruits. Chinese Agri. Sci. Bull. 20, 235-239 (2004).

50) Nie, L.C.; Sun, J.S. Relationship between the content of phenolic compounds and taste of astringency and bitterness in apple fruit. Acta Hort. Sinica. 32, 778$782(2005)$.

51) Keutgen, A.J.; Pawelzik, E. Contribution of amino acids to strawberry fruit quality and their relevance as stress indicators under $\mathrm{NaCl}$ salinity. Food Chem. 111, 642-647 (2008).

52) Liu, N.; Yue, D.; Lu, B.; Tian, S.B.; Zhang, H.; Zhu, L.Y. Analysis of amino acid composition and flavor qualityrelated indexes of yellow-and red-fruited tomato species. J. Food Sci. Biotech. 35, 1081-1087 (2016).

53) Peng, Z.F.; Wang, W.; Ye, Q.H.; Chen, Q.X. Quantitative analysis of amino acids in Chinese olive using high performance liquid chromatography-tandem mass spectrometry. Food Sci. 39, 231-238(2018).

54) Herrera, E.A. Early harvest and oven drying temperatures influence pecan kernel flavor. Hort. Sci. 29, 671672 (1994). 